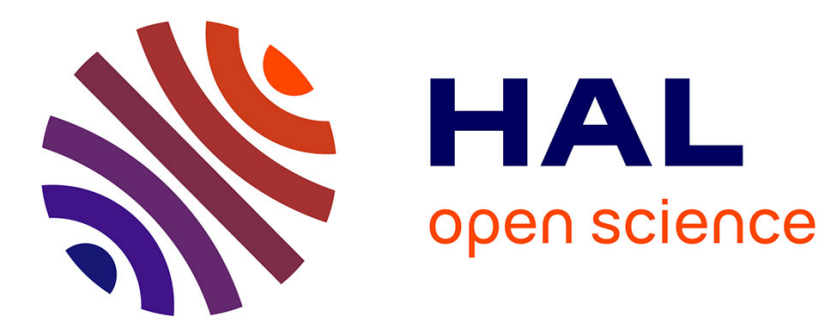

\title{
Effects of forest management on the amount of deadwood in Mediterranean oak ecosystems
}

Alessandro Paletto, Isabella de Meo, Paolo Cantiani, Fabrizio Ferretti

\section{To cite this version:}

Alessandro Paletto, Isabella de Meo, Paolo Cantiani, Fabrizio Ferretti. Effects of forest management on the amount of deadwood in Mediterranean oak ecosystems. Annals of Forest Science, 2014, 71 (7), pp.791-800. 10.1007/s13595-014-0377-1 . hal-01102882

\section{HAL Id: hal-01102882 \\ https://hal.science/hal-01102882}

Submitted on 13 Jan 2015

HAL is a multi-disciplinary open access archive for the deposit and dissemination of scientific research documents, whether they are published or not. The documents may come from teaching and research institutions in France or abroad, or from public or private research centers.
L'archive ouverte pluridisciplinaire HAL, est destinée au dépôt et à la diffusion de documents scientifiques de niveau recherche, publiés ou non, émanant des établissements d'enseignement et de recherche français ou étrangers, des laboratoires publics ou privés. 


\title{
Effects of forest management on the amount of deadwood in Mediterranean oak ecosystems
}

\author{
Alessandro Paletto • Isabella De Meo • Paolo Cantiani • \\ Fabrizio Ferretti
}

Received: 29 November 2013 / Accepted: 8 April 2014 /Published online: 15 May 2014

(C) INRA and Springer-Verlag France 2014

\begin{abstract}
- Context Deadwood is an important habitat for vertebrate and invertebrate species, a key factor in the nutrient cycle and a valuable carbon pool. Difference in the deadwood C stock depends on many variables such as forest type, microclimate and forest management.

- Aims We investigated the relationship between $\mathrm{C}$ stock in deadwood and forest management in oak stands of southern Italy.

- Methods Deadwood C stock was quantified in 74 forest stands under intensive, extensive or multifunctional management. The relationship between management and $\mathrm{C}$ stock in deadwood was assessed taking into account the decay class and the type of deadwood (snags, stumps and logs).

- Results Intensively managed forests are characterized by significantly lower mean levels of deadwood $\mathrm{C}$ than the other forms of management. Multifunctional management resulted in the highest level of $\mathrm{C}$, mainly in logs and snags, while
\end{abstract}

Handling Editor: Andreas Bolte

Contribution of the co-authors Alessandro Paletto and Isabella De Meo analysed the data and wrote the paper; Paolo Cantiani and Fabrizio Ferretti designed the research and experiment and supervised the work.

A. Paletto $(\bowtie)$

Consiglio per la Ricerca e la Sperimentazione in Agricoltura-Forest Monitoring and Planning Research Unit (CRA-MPF), P.za Nicolini 6, 38123, Villazzano Trento, Italy

e-mail: alessandro.paletto@entecra.it

I. De Meo

Consiglio per la Ricerca e la Sperimentazione in Agricoltura Agrobiology and Pedology Centre (CRA-ABP), P.za D'Azeglio 30, 50121 Florence, Italy

P. Cantiani $\cdot$ F. Ferretti

Consiglio per la Ricerca e la Sperimentazione in Agricoltura Forestry Research Centre (CRA-SEL), Via S. Margherita 80, 52100 Arezzo, Italy extensive management resulted in high levels of $\mathrm{C}$ storage concentrated in snags.

- Conclusion Results of the research highlight that forest management practices greatly influence the quantitative and qualitative presence of deadwood in forests.

Keywords Standing dead trees - Lying deadwood. Stumps - Carbon pool · Forest management . Collina Materana (Italy) · Deadwood - Extensive management . Intensive management - Multifunctional management

\section{Introduction}

According to the FAO's Global Forest Resources Assessment 2005 (FAO 2004), forest deadwood can be defined as all nonliving woody biomass not contained in the litter, either standing, lying on the ground or in the soil; deadwood includes the following components (Hagemann et al. 2009): standing dead trees, lying dead trunks and fallen branches and twigs and stumps.

During recent decades, the perception of the presence of deadwood in forest ecosystems has changed considerably (Merganičová et al. 2012). In the past, it was perceived by forest managers as an undesirable component in forest ecosystems: a potential source of pests and diseases (Marage and Lemperiere 2005), a cause of risk for forest fires (Thomas 2002; Radu 2006) and an obstacle to silvicultural activities (Travaglini et al. 2007). Currently, deadwood is regarded as an important structural and functional component of forests (Harmon et al. 1986) because it is an essential substrate for numerous insects as well as fungi (Nordén et al. 2004; Herrero et al. 2014); a key factor in the nutrient cycle of $\mathrm{C}, \mathrm{N}$ and $\mathrm{Mg}$ (Krankina and Harmon 1994; Holub et al. 2001); a fundamental element in the ecological and soil hydrological processes 
(Bragg and Kershner 1999) and a valuable forest carbon pool (Ravindranath and Ostwald 2008).

According to Brown (2002), standing and lying deadwood accounts for $10-20 \%$ of the above-ground biomass in mature forests, yet few studies have provided an estimate of the deadwood C stock (Kueppers et al. 2004).

Nowadays, an estimate of the C stock in deadwood is required for reporting to the Kyoto Protocol (1997), as well as to the United Nations Framework Convention on Climate Change (1992) (Tobin et al. 2007). According to these political documents, the carbon stocks in forests and their changes must be monitored (Rock et al. 2008; Teissier du Cros and Lopez 2009). These changes depend on many variables including forest type, micro-climatic conditions, weather conditions and forest management. The intensity of management and the silvicultural practices adopted can affect the amount and quality of deadwood in forest ecosystems (Green and Peterken 1997). In managed forests, the amount of deadwood is reduced by extraction of timber and wood biomass (Vallauri et al. 2003; Verkerk et al. 2011), while in protected areas or in forests managed according to 'close-to-nature' principles, the amount is significantly greater (Kirby et al. 1998).

The paper is primarily focused on analysing the relationship between forest management practices and deadwood in forest. In particular, the relationships between the volume and carbon stock of deadwood and forest management were investigated. The authors hypothesized that the distribution of deadwood volume by component and by decay class are closely related to the past forest management. Moreover, the importance of deadwood for biodiversity and habitat conservation was investigated considering the relationships between the diameter distribution of deadwood and the habitat for wood-living species. Hence, in a 'close-to-nature' management approach, a prevalence of logs and snags with high diameters (habitat trees) and an equal distribution between decay classes should be favoured.

The analysis was conducted in a case study (Collina Materana, Italy) where three forms of forest management are prevalent: (1) intensive for timber and bioenergy production, (2) extensive for firewood home use and (3) multifunctional for wood, non-timber products and environmental services. The relationship between form of forest management and deadwood C stock was investigated, taking into account the deadwood component (snags, logs and stumps) and the decay class (using a five-class system).

\section{Materials and methods}

\subsection{Study area}

The study area is the Collina Materana district $\left(45^{\circ} 5^{\prime} 3^{\prime \prime} \mathrm{N}\right.$, $12^{\circ} 0^{\prime} 4^{\prime \prime} \mathrm{E}$ ) located in the central-western part of the Matera
Province in the Basilicata Region (southern Italy). The district occupies 60,784 ha and has a population of 14,051 inhabitants. The climate is oro-mediterranean, with a warm, dry summer and a cold winter. Forests occupy 22,304 ha (37\% of the region), and the most widespread forest types are (EEA 2006) (1) Turkey oak, Hungarian oak and Sessile oak (Quercus cerris L. dominant); (2) Downy oak forest (Quercus pubescens Willd. dominant) and (3) Mediterranean evergreen oak forest (Quercus ilex L. dominant).

In the past, coppices represented the main forest system and forest management was mainly aimed at firewood production (Paletto et al. 2012a). Recently, a substantial change, in terms of area, between coppices and high forests has taken place. Coppices are clear cutted with release of standards, and the rotation period has been progressively increased in recent decades.

High forests were traditionally managed with the shelterwood system, but the gradual abandonment of any treatments has lead these stands to natural evolution, which is now the most common management system.

\subsection{Field measurements}

Qualitative and quantitative characterization of selected forest stands stratified by forest category was conducted. Measurements were taken from a sampling set of forest inventory plots.

A geo-referenced $1-\mathrm{km} \times 1-\mathrm{km}$ grid with random origin was generated. A point with random coordinates was positioned in each square of the grid. Eventually, all points were overlapped to Basilicata forest types map (Costantini et al. 2006) in order to select the reference sample plots (227 plots). These sample plots were surveyed with qualitative measurements. Approximately one-third of the sample (74 plots) was randomly chosen to provide quantitative measurements of forest stand.

In each sample plot $\left(531 \mathrm{~m}^{2}\right)$, the main dendrometric parameters were classified/measured. The following parameters were considered: species, number of stems, diameter at breast height ( $\mathrm{dbh}>4.5 \mathrm{~cm})$, tree height of five sample trees, regeneration and deadwood. Forest management and harvesting methods were also described.

In each sample plot, the volume of forest deadwood was estimated, taking into account three main integrative features (Næsset 1999): component (standing dead trees or snags, lying dead woody debris or logs and stumps), origin (coniferous or deciduous species) and decay class. We considered lying dead woody debris, standing dead trees and stumps with a minimum diameter of $10 \mathrm{~cm}$ because they are the most important deadwood components for carbon storage. For each standing dead tree in the plot, the diameter at breast height (dbh) and the height were measured, while for the lying 
woody debris, the diameters at three cross sections (minimum, maximum and medium) and the length were measured in order to estimate the volume.

The decay rate is a very important variable in the carbon store estimation because it influences the dynamics of carbon release and sequestration (Stokland et al. 2004; Zell et al. 2009). As in the American Forest Inventory (Waddell 2002) and the main European forest inventories (Paletto and Tosi 2010; Sandström et al. 2007), a five-class system was used. The five decay classes were evaluated on the basis of softness of wood and other visible characteristics (rot extension and development of fungus mycelium), structure of the bark and presence of small branches with a diameter less than $3 \mathrm{~cm}$ (Hunter 1990; Montes et al. 2004).

The above mentioned forest types were divided into two groups according to forest system: coppices with standards (100-150 standards per hectare) and high forests. Coppices are regularly clear-cut every 30 years $(Q$. cerris L. and Q. pubescens Willd. dominant forests) or every 45 years (Q. ilex L. dominant forests). In marginal coppices, rotation age is increased. In other cases, coppices are abandoned due to the difficult accessibility and to the low fertility. These coppices are evolving towards a one-/two-storey high stands.

High forests (originated from seed or converted from coppice) with generally monolayer structure are managed using shelterwood system. Rotation is usually 100 years with light to moderate thinnings from below. Abandoned high forests are characterized by high stem density, homogeneous structure and high canopy cover (more than $80 \%$ ). These type of stands have not reached yet physiological maturity.

Three main management approaches were investigated: (1) extensive forest management, (2) intensive forest management and (3) multifunctional forest management. Extensive and intensive forestry are both aimed at producing forest products (bioenergy, firewood and timber) and financial returns, but with a difference in the type and intensity of management. According to Helms (1998, p.61) intensive forestry can be defined as 'the practice of forestry to obtain a high level of volume and quantity of outturn per unit area through the application of the best techniques of silviculture and management'. By contrast, extensive forestry is (Helms 1998, p.98) 'the practice of forestry on a basis of low operating and investment costs per acre'. Multifunctional forest management has the main purpose of also enhancing nonproductive forest functions. The objective of this approach is to integrate into the forest management the nonproductive aspects - such as sociocultural and environmental functions - in order to enhance the ecosystem goods and services (Führer 2000).

In the case study, the three different management approaches were distinguished, based on qualitative and quantitative indicators (Table 1).
The sampling plots were distributed with 44 in extensive management forests, 18 in intensive management forests and 12 in multifunctional management forests.

\subsection{Volume estimation}

The volume of deadwood was calculated using a geometric system and applying, for the snag, the stereometric equation of the first Italian NFI. Standing dead tree volume $\left(V_{\mathrm{s}}\right)$ was calculated from stand basal area (BA) and tree height obtained from the hypsometric curve $(h)$, using the standard biometric equation (Cannell 1984):

$V_{\mathrm{s}}=f \cdot \mathrm{BA} \cdot h$

which includes a standard stem form factor $(f)$ of 0.5 .

Lying deadwood volume $\left(V_{1}\right)$ and stump volume $\left(V_{\text {st }}\right)$ were calculated using the following formula:

$V=\frac{\pi}{4} \cdot h \cdot\left(\frac{D+d}{2}\right)^{2}$

where $h$ is the height or length measured (m), $D$ is the maximum diameter $(\mathrm{m}), d$ is the minimum diameter $(\mathrm{m})$.

The total volume of deadwood in a forest $\left(V_{\mathrm{d}}\right)$ is the sum of three components:

$V_{\mathrm{d}}=V_{\mathrm{s}}+V_{1}+V_{\mathrm{st}}$

\subsection{Carbon stock estimation}

The deadwood carbon stock was estimated by converting the deadwood volume into the mass of carbon stored in this pool. Volumes in plots were converted to biomass using the appropriate basic wood density value estimated by the second Italian NFI (INFC 2007) distinguished by components (lying deadwood, standing dead trees and stumps), origin (coniferous and broadleaves) and decay classes (Table 2).

The overall deadwood biomass was finally converted to the corresponding carbon store. Generally, in the literature, it is assumed that the carbon content of deadwood is approximately $51 \%$ (Sollins et al. 1987) or $50 \%$ (Coomes et al. 2002), but direct chemical analysis for carbon shows that there are differences linked to the species and analysis method. Matthews (1993) showed that the carbon content of oak wood obtained by direct analysis is $48.95 \%$ while that calculated from extractive analysis data is $49.40 \%$. In the present research, the carbon content obtained by direct analysis is used considering the average value estimated for several North American and European oak species. The several studies considered in 
Table 1 Description of the management approaches

\begin{tabular}{|c|c|c|c|}
\hline & Extensive forest management & Intensive forest management & Multifunctional forest management \\
\hline Description & $\begin{array}{l}\text { Marginal forests due to the low fertility or to the } \\
\text { difficult accessibility (too far from forest road } \\
\text { or characterized by difficult site conditions) }\end{array}$ & Usually managed forests & $\begin{array}{l}\text { Forests characterized by multiple use } \\
\text { (biodiversity conservation, tourism } \\
\text { and recreation, protected areas) }\end{array}$ \\
\hline \multirow[t]{4}{*}{ Indicators } & Coppice, basal area $<15 \mathrm{~m}^{2} \mathrm{ha}^{-1}$ & Positive stumpage value & Forest showing clear signs of grazing \\
\hline & High forest, basal area $<20 \mathrm{~m}^{2} \mathrm{ha}^{-1}$ & Forests showing clear signs of cutting & Retention of large diameter trees \\
\hline & Slope $>80 \%$ & $\begin{array}{l}\text { Forest showing clear signs of } \\
\text { regeneration phase }\end{array}$ & Protected areas \\
\hline & Mechanized harvesting is not applicable & Mechanically harvestable & Equipped recreation area \\
\hline
\end{tabular}

the meta-analysis have estimated the carbon content in the oak species in a range between 46.8 and $50.6 \%$ (direct analysis).

$C=\sum_{i=1}^{i=5} V_{\mathrm{i}} \cdot \mathrm{BD} \cdot 0.4895$

where $C$ is the total carbon stock, $V_{\mathrm{i}}$ is the volume of deadwood per decay class $\left(\mathrm{m}^{3}\right), \mathrm{BD}$ is the basic wood density $\left(\mathrm{g} / \mathrm{m}^{3}\right)$ and 0.4895 is the carbon factor of oak wood obtained by direct analysis.

\subsection{Statistical analysis}

Statistical analysis, using STATISTICA for Windows, version 7.1, was performed to investigate differences in deadwood (volume of deadwood and carbon stock) among different management approaches. To test if the collected data were normally distributed, the Shapiro Wilk normality test was performed (Shapiro and Wilk 1965). Since data distribution was not normal $(p<0.05)$, nonparametric tests were used to analyse data among the quantitative variables. The KruskalWallis ANOVA test assesses the hypothesis that in the comparison, different samples are drawn from the same distribution or from distributions with the same median. When
ANOVA revealed significant relationships among deadwood and management approaches, we used the Kruskal-Wallis multiple comparison test for post hoc comparisons, to know which management approach differed from the others. All statistical tests were assessed at the $\alpha=0.05$ level.

Differences in the diameter distribution of deadwood among variously managed plots were tested using chi-square test $(p<0.05)$.

\section{Results}

\subsection{Volume of deadwood}

Deadwood volume depends on forest characteristics and dynamics but is also highly influenced by management practices (Lombardi et al. 2008; Pedlar et al. 2002). The total volume of deadwood was estimated to be $7.64 \mathrm{~m}^{3} \mathrm{ha}^{-1}$. The distribution of volume per component shows that lying deadwood has a mean of 45 pieces ha ${ }^{-1}$ and $2.68 \mathrm{~m}^{3} \mathrm{ha}^{-1}$, snags have a mean of 9 pieces $\mathrm{ha}^{-1}$ but constitutes the major part of the volume with $3.38 \mathrm{~m}^{3} \mathrm{ha}^{-1}$, while the stumps have a mean of 47 pieces $\mathrm{ha}^{-1}$ and a volume of $1.58 \mathrm{~m}^{3} \mathrm{ha}^{-1}$. All data are characterized by a high level of variance because in many plots one or more components of deadwood are absent (40.5\% of plots for logs, $75.7 \%$ for snags and $37.8 \%$ for stumps).

Table 2 Basic wood density $\left(\mathrm{g} / \mathrm{m}^{3}\right)$ of deadwood by component, origin and decay class

\begin{tabular}{|c|c|c|c|c|c|c|}
\hline \multirow[t]{2}{*}{ Decay class } & \multicolumn{2}{|c|}{ Coarse woody debris } & \multicolumn{2}{|c|}{ Standing dead trees } & \multicolumn{2}{|l|}{ Stumps } \\
\hline & Conifers & Broadleaves & Conifers & Broadleaves & Conifers & Broadleaves \\
\hline 1 & 0.4115 & 0.5130 & 0.4429 & 0.5228 & 0.4595 & 0.5113 \\
\hline 2 & 0.3898 & 0.4686 & 0.4239 & 0.5258 & 0.4509 & 0.4943 \\
\hline 3 & 0.3420 & 0.4443 & 0.3843 & 0.5137 & 0.3979 & 0.4510 \\
\hline 4 & 0.2954 & 0.3440 & 0.3544 & 0.4386 & 0.3447 & 0.4104 \\
\hline 5 & 0.2659 & 0.2551 & 0.3723 & - & 0.2712 & 0.3068 \\
\hline
\end{tabular}

Source: modified by Di Cosmo et al. (2013) 
Considering the distribution of deadwood volume by decay class, the results show that volumes are highest in the third decay class ( $25 \%$ of the total), while the most decomposed classes (fourth and fifth) together account for $39 \%$ and the least decomposed classes (first and second) together account for $36 \%$. Considering the three deadwood components (Fig. 1), we observe that volume of snags is concentrated in the first $(36 \%)$ and third class $(33 \%)$, while the volume of logs and stumps is concentrated in the most decomposed classes.

The results are comparable with those of the second Italian NFI (Pignatti et al. 2009; Di Cosmo et al. 2013) which estimates the value of deadwood volume in Italy at $8.8 \mathrm{~m}^{3} \mathrm{ha}^{-1}\left(5.4 \mathrm{~m}^{3} \mathrm{ha}^{-1}\right.$ standing dead trees, $1.9 \mathrm{~m}^{3} \mathrm{ha}^{-1}$ lying deadwood and $1.5 \mathrm{~m}^{3} \mathrm{ha}^{-1}$ stumps) and $2.2 \mathrm{~m}^{3} \mathrm{ha}^{-1}$ in Basilicata region (where the study area is located) $\left(1.1 \mathrm{~m}^{3} \mathrm{ha}^{-1}\right.$ standing dead trees, $0.6 \mathrm{~m}^{3} \mathrm{ha}^{-1}$ lying deadwood and $0.5 \mathrm{~m}^{3} \mathrm{ha}^{-1}$ stumps). Other local studies made in the southern Italian Apennines showed slightly higher values: chestnut coppices in Calabria (Aspromonte) $21 \mathrm{~m}^{3} \mathrm{ha}^{-1}$ (La Fauci and Mercurio 2008), Turkey oak forests in Molise $9.3 \mathrm{~m}^{3} \mathrm{ha}^{-1}$ (Barreca et al. 2008), mixed oak forests in Molise $15.1 \mathrm{~m}^{3} \mathrm{ha}^{-1}$ (Marchetti and Lombardi 2006) and Downy oak and Turkey oak forests in Basilicata $8.8 \mathrm{~m}^{3} \mathrm{ha}^{-1}$ (Paletto et al. $2012 b)$. This variability is most probably not only due to the natural variability in deadwood amounts related to forest productivity and stand dynamics (Siitonen 2001) but also to the influence of different forest management activities (Pregitzer and Euskirchen 2004).

Considering the distribution of deadwood volume by management approach, the results show that deadwood volume decreases from multifunctional management to intensive management which is associated with lower deadwood volumes (3.14 $\mathrm{m}^{3} \mathrm{ha}^{-1}: 1.14 \mathrm{~m}^{3} \mathrm{ha}^{-1} \operatorname{logs}, 1.07 \mathrm{~m}^{3} \mathrm{ha}^{-1}$ snags and $0.93 \mathrm{~m}^{3} \mathrm{ha}^{-1}$ stumps). Forests under extensive management have a mean value of $8.54 \mathrm{~m}^{3} \mathrm{ha}^{-1}\left(2.69 \mathrm{~m}^{3} \mathrm{ha}^{-1} \operatorname{logs}\right.$, $4.38 \mathrm{~m}^{3} \mathrm{ha}^{-1}$ snags and $1.47 \mathrm{~m}^{3} \mathrm{ha}^{-1}$ stumps), while forests under multifunctional management have the highest value (11.21 $\mathrm{m}^{3} \mathrm{ha}^{-1}: 4.95 \mathrm{~m}^{3} \mathrm{ha}^{-1} \operatorname{logs}, 3.24 \mathrm{~m}^{3} \mathrm{ha}^{-1}$ snags and $3.02 \mathrm{~m}^{3} \mathrm{ha}^{-1}$ stumps). Large reductions in deadwood are due to intensive forest management practices (Kirby et al. 1998; Lombardi et al. 2008), with the extraction of biomass for renewable energy production. On average, the quantity of deadwood in unmanaged forests is a third higher than that in managed forests (Duvall and Grigal 1999; Green and Peterken 1997). In a worked coppice with standards actively cut, the authors estimated a volume of fallen wood of $11.9 \mathrm{~m}^{3} \mathrm{ha}^{-1}$, while for a high oak forest under extensive management the estimated volume of deadwood was $23.1 \mathrm{~m}^{3} \mathrm{ha}^{-1}$ (Kirby et al. 1998). For intensively managed forests in Sweden, Kruys et al. (1999) and Fridman and Waldheim (2000) observe a lying woody debris volume from 1.7 to $9.7 \mathrm{~m}^{3} \mathrm{ha}^{-1}$. Results of the present study confirm this tendency, with a deadwood decrease from multifunctional to intensive management.

For deadwood volume data, statistically significant differences among the three management approaches were found. The deadwood volume in the intensively managed forests is significantly lower than the volume in multifunctional forests (Kruskal-Wallis post hoc test $H=7.22 ; d f=2, p$ value=0.027).

Results show (Fig. 2) that the proportion of deadwood component types (snags, logs and stumps) varies with the management approach. Forests under extensive management have the highest volumes of snags, presumably because many trees are not removed, especially the larger ones, as occurs, by contrast, in logged sites. The highest presence of stumps in intensively managed forests is related to the cutting that occurs frequently over time.

\subsection{Carbon stock in deadwood}

The C stocks were calculated from the volumes taking into account decay class and deadwood components. The total $\mathrm{C}$ present in the Collina Materana forests was estimated to be
Fig. 1 Distribution of deadwood volume $\left(\mathrm{m}^{3} / \mathrm{ha}\right)$ by decay class and component

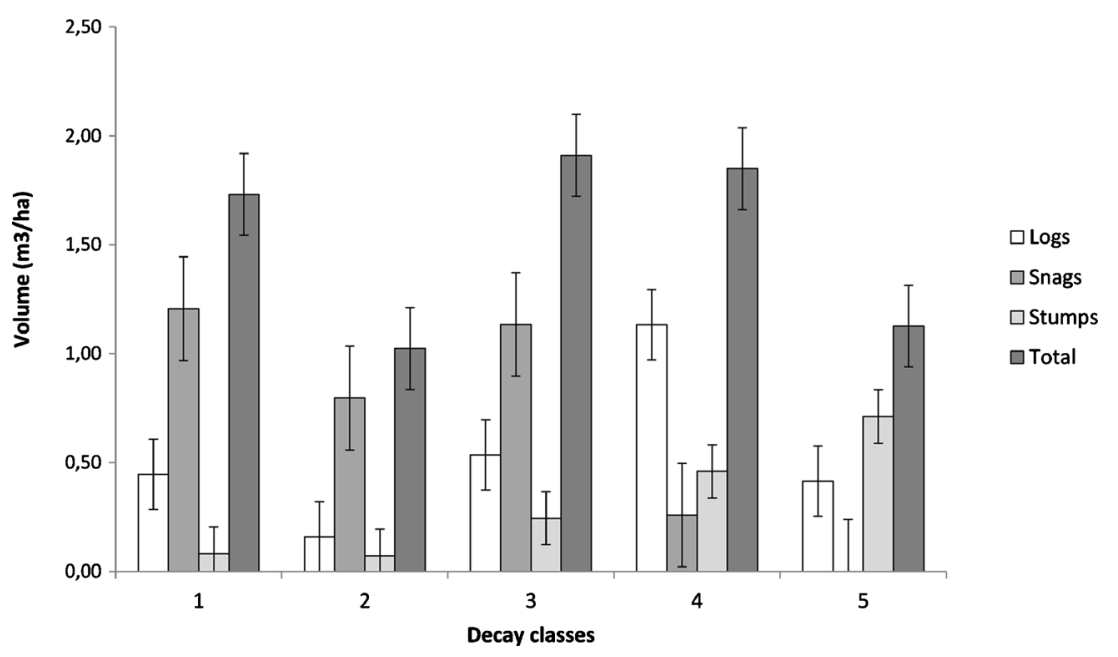


Fig. 2 Percentage distribution of deadwood volume in the different components by forest management

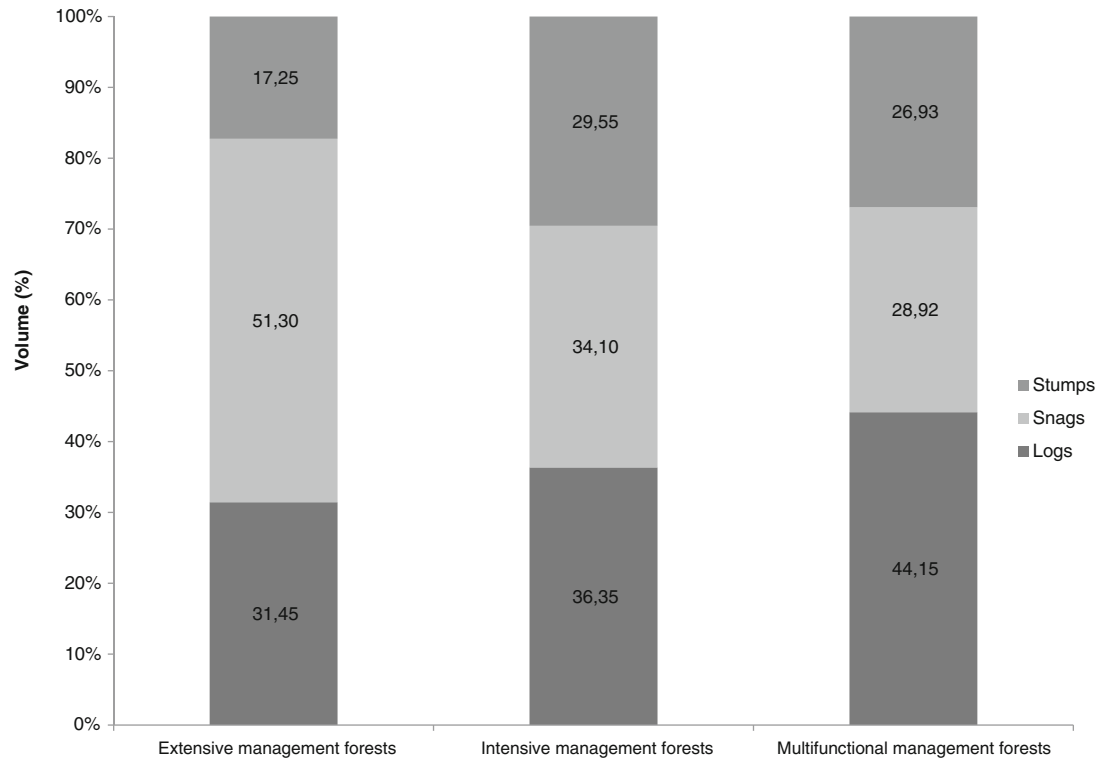

$1.62 \mathrm{tC} \mathrm{ha}^{-1}$, distributed as shown in Table 3 and Fig. 3 among the various components and decay classes.

The carbon stored in deadwood is strongly influenced by forest management. The forests under multifunctional management have a high level of carbon storage $\left(2.28 \mathrm{tC} \mathrm{ha}^{-1}\right)$, concentrated in the logs and the snags $0.98 \mathrm{tC} \mathrm{ha}^{-1} \operatorname{logs}, 0.82$ tC ha ${ }^{-1}$ snags and $0.48 \mathrm{tC} \mathrm{ha}^{-1}$ stumps. Instead, extensively managed forests have high levels of carbon storage concentrated in the snags $\left(1.10 \mathrm{tC} \mathrm{ha}^{-1}\right)$, while logs and stumps provide a limited contribution to the overall carbon stored in deadwood (0.49 tC ha ${ }^{-1} \operatorname{logs}, 0.28 \mathrm{tC} \mathrm{ha}^{-1}$ stumps). Intensively managed forests have low levels of carbon storage ( $\left.0.70 \mathrm{tC} \mathrm{ha}^{-1}\right)$, but a balanced distribution between components $\left(0.24 \mathrm{tC} \mathrm{ha}^{-1} \operatorname{logs}, 0.27 \mathrm{tC} \mathrm{ha}^{-1}\right.$ snags and $0.19 \mathrm{tC} \mathrm{ha}^{-1}$ stumps). These results confirm the analysis of Krankina and Harmon (1994) whereby intensive forest management reduces forest carbon stocks to $10-25 \%$ of the potential level.

The Kruskal-Wallis ANOVA revealed a significant result $(H=6.29 ; d f=2, p$ value $=0.043)$. However, among the management approaches, there were no significant differences in the carbon stored in deadwood, as indicated by the KruskalWallis multiple comparison test.

\subsection{Diameter distribution}

The diameter of the wood pieces is positively correlated with biodiversity and habitat conservation because many woodliving species prefer large deadwood (Kruys et al. 1999; Jönsson and Jonsson 2007). From a biodiversity point of view, importance should be given also to the diversity of habitats available, giving more weight to rare elements, such as large diameter trees (Rondeux and Sanchez 2010). Retention of larger diameter trees in particular may have a positive impact on forest carbon stocks (Nunery and Keeton 2010).

The results of the present study show that the habitat trees with an average diameter greater than $30 \mathrm{~cm}$ are 19 pieces ha ${ }^{-1}$ for snags and 75 pieces $\mathrm{ha}^{-1}$ for logs. Regarding the habitat trees, according to the literature, a minimum number of 5-10 trees $\mathrm{ha}^{-1}$ is required for biodiversity conservation (Mason et al. 2005). In the case study, the amount of habitat trees is above this minimum level, indicating the value of the Collina Materana forests for habitat and biodiversity conservation.

Analysis of the diameter distribution of wood elements in the various deadwood compartments shows a concentration of logs in the lower size classes (diameter less than $20 \mathrm{~cm}$ ) and a large
Table 3 Distribution of C stock in the deadwood component and decay classes considering the type of management

\begin{tabular}{|c|c|c|c|c|c|c|c|c|c|}
\hline \multirow[t]{2}{*}{ Decay class } & \multicolumn{3}{|c|}{ Extensive management } & \multicolumn{3}{|c|}{ Intensive management } & \multicolumn{3}{|c|}{ Multifunctional management } \\
\hline & Logs & Snags & Stumps & Logs & Snags & Stumps & Logs & Snags & Stumps \\
\hline 1 & 0.07 & 0.36 & 0.01 & 0.01 & 0.27 & 0.07 & 0.44 & 0.19 & 0.00 \\
\hline 2 & 0.05 & 0.28 & 0.02 & 0.02 & 0.00 & 0.01 & 0.02 & 0.22 & 0.03 \\
\hline 3 & 0.07 & 0.37 & 0.07 & 0.20 & 0.00 & 0.04 & 0.15 & 0.42 & 0.01 \\
\hline 4 & 0.24 & 0.09 & 0.14 & 0.02 & 0.00 & 0.03 & 0.26 & 0.00 & 0.01 \\
\hline 5 & 0.05 & 0.00 & 0.05 & 0.00 & 0.00 & 0.04 & 0.11 & 0.00 & 0.43 \\
\hline Total & 0.48 & 1.10 & 0.29 & 0.25 & 0.27 & 0.19 & 0.98 & 0.83 & 0.48 \\
\hline
\end{tabular}


Fig. 3 Distribution of the carbon stock in deadwood $\left(\mathrm{tC} \mathrm{ha}^{-1}\right)$ by forest management (KruskalWallis ANOVA test, $p$ value $=$ 0.043 )

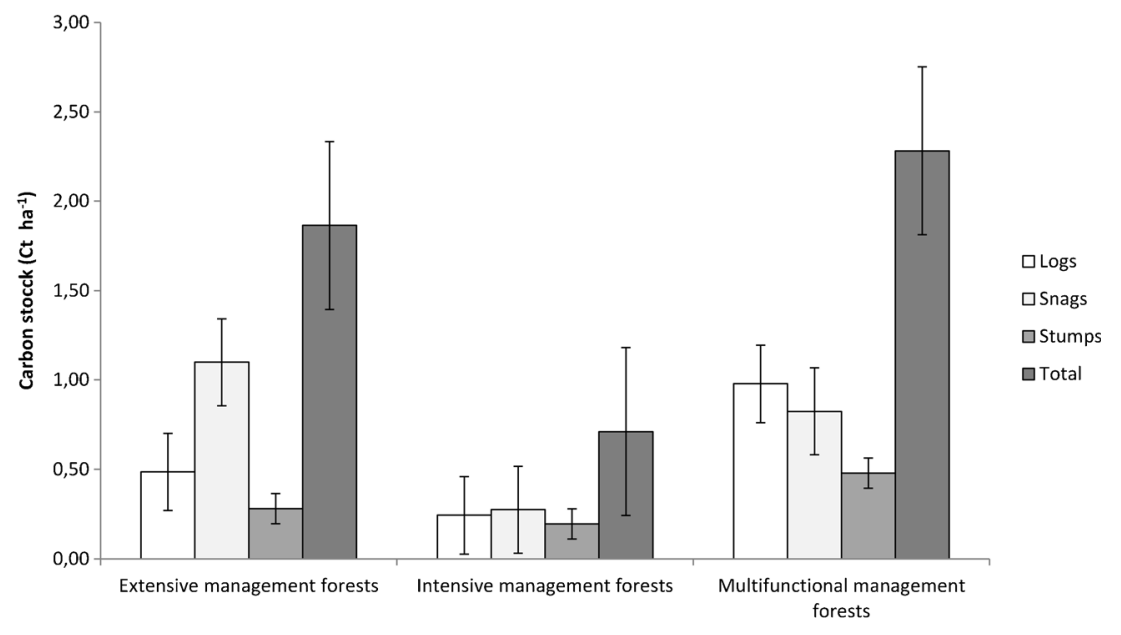

number of stumps with a mean diameter greater than $30 \mathrm{~cm}$ (Fig. 4a). These results are in line with those obtained by Kruys et al. (1999) who noted a strongly skewed distribution towards very small diameter logs (63\% of all logs were $<10 \mathrm{~cm}$ maximum diameter). When considering different management approaches, it seems that extensively managed forests (Fig. 4b) follow the same trend as multifunctional managed forests (Fig. 4c). Conversely, the intensively managed forests (Fig. 4d) have a dominance of stumps in all DBH size classes and in particular, in small (diameter between 10 and $20 \mathrm{~cm}$ ) and large (diameter more than $40 \mathrm{~cm}$ ) classes. A chi-square test revealed a significant difference in the diameter distribution of logs present in the extensively managed plots compared to the intensively and multifunctional managed plots $\left(\chi^{2}=31.03, p=0.001\right)$.

\section{Discussion}

The results show that the average volume of deadwood in the Collina Materana district is in line with the national average,
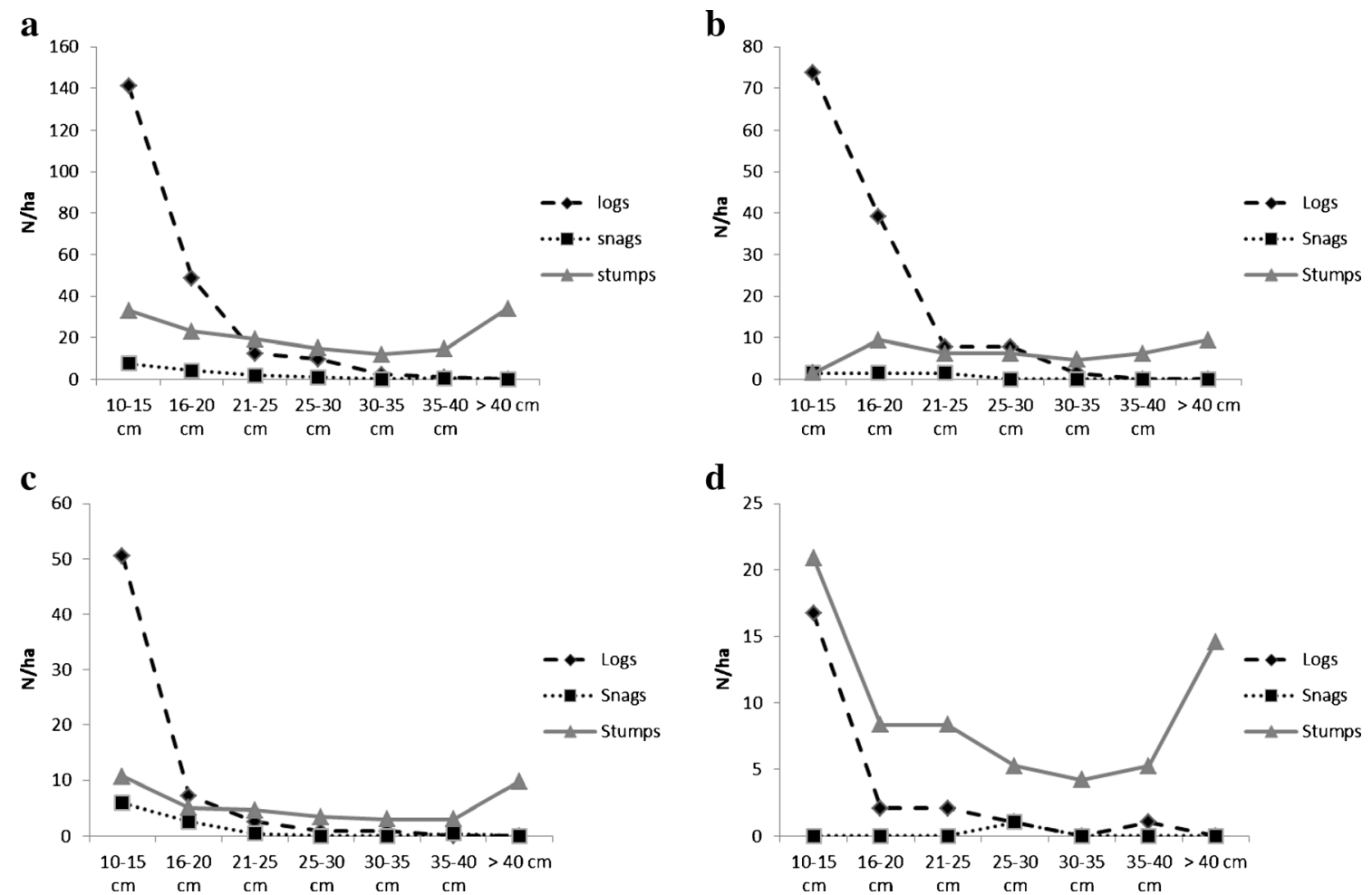

Fig. 4 Diameter distribution of wood elements: all forests (a), extensively managed forests (b), multifunctionally managed forests (c) and intensively managed forests $(\mathbf{d})$ 
but also show great variability in deadwood amounts. For this reason, it is important to state that this study provides information for oak forest types in the Mediterranean area, not necessarily representative of the overall types.

The variation of deadwood volume in decay class distribution gives an indication of the temporal variation in tree felling and mortality and can be used as an indicator of the history of a forest (Rouvinen et al. 2005). When deadwood shows all decay classes, as occurs in the present case study, the death of the plants has probably occurred evenly over a long time.

Results also confirmed that extensively managed stands contained more deadwood than intensively managed ones. In addition, multifunctional management provided larger quantities of deadwood than the least intense productionoriented management. This tendency is coherent with the purpose of the three management approaches. In intensively managed forests, silvicultural treatments are mainly oriented to wood production. In these situations, harvesting means not only the extraction of timber but also the removal of wood residues from the ground. At the opposite extreme, multifunctional management is basically aimed at exploiting nonproductive forest functions as well as increasing deadwood with ad hoc management strategies, in order to enhance forest biodiversity. Specific silvicultural interventions (i.e. retention of large diameter snags and logs) are finalized to the maintenance of deadwood habitats. In high forests where grazing pressure is more intense, a particular attention is given to the retention of logs for tree regeneration. In these situations, logs create natural exclosures and permit patches of ungrazed vegetation to develop (Bobiec 2002).

Extensively managed forests are usually marginal forests with a low fertility and/or a difficult accessibility. In these stands, the increase of the coppice rotation generates a higher mortality of the shoots and an improvement of deadwood.

Since the type of management greatly influences the presence of deadwood in forests and the ecological role of deadwood (habitat for species, a key factor in the nutrient cycle and relevant carbon pool), silvicultural strategies can be implemented in order to maintain or increase the volume of deadwood in the Collina Materana forests.

Regarding coppice systems, the quantity of deadwood is correlated with the duration of rotation. In this type of stand, an increase in deadwood could be obtained by leaving a few standards to an indefinite age, or by girdling them (Mason et al. 2005). However, particular attention should be given to the excessive shading caused by their crowns, since this may hamper the development of coppice shoots. For this reason, a balance between productive function and environmental benefits due to the increase in deadwood could be achieved by releasing 3-4 standards per hectare in Turkey oak and Downy oak coppices and a slightly higher number in Holm oak coppices, this species being more tolerant of shade.
Broadleaved high forests return a larger volume of deadwood to the soil than coppices, as well as a greater number of standing dead trees. However, the quantity of deadwood is influenced by the type of silvicultural treatment. An increase in deadwood in broadleaved oak forests can be obtained by: (1) extending the duration of rotation, (2) leaving some individuals to indefinite ageing at the time of the final felling and (3) implementing selective thinning of the dominant layer and releasing a dominated layer for the provision of deadwood.

At present, many private forests of the Collina Materana, under the heading 'extensive management', are completely unmanaged. In this case, deadwood is extensively provided and strategies to increase its amount are pointless.

The present research evidenced that there is a clear impact of human interventions on quantity of deadwood and that management strategies deeply influence forest ecosystems biodiversity. Deadwood has not been extensively investigated in Mediterranean-oak ecosystems, and field surveys could be used to enrich a systematic and comparative programme of research whose results can implement the development of guidelines concerning deadwood management.

\section{References}

Barreca L, Cutini A, Mercurio R (2008) Caratterizzazione della necromassa in boschi di farnetto (Quercus frainetto Ten.) della Calabria. Forest 5:187-194

Bobiec A (2002) Living stands and dead wood in the Białowieża forest: suggestions for restoration management. For Ecol Manag 165:125140

Bragg DC, Kershner JL (1999) Coarse woody debris in riparian zones. J For 4:30-35

Brown S (2002) Measuring carbon in forests: current status and future challenges. Environ Pollut 116:363-372

Cannell MGR (1984) Woody biomass of forest stands. For Ecol Manag 8: 299-312

Coomes DA, Allen RB, Sčoty NA, Goulding C, Beets P (2002) Designing systems to monitor carbon stocks in forests and shrublands. For Ecol Manag 164:89-108

Costantini G, Bellotti A, Mancino G, Borghetti M, Ferrara A (2006) Carta Forestale della Basilicata. INEA

Di Cosmo L, Gasparini P, Paletto A, Nocetti M (2013) Deadwood basic density values for national-level carbon stock estimates in Italy. For Ecol Manag 295:51-58

Duvall MD, Grigal DF (1999) Effects of timber harvesting on coarse woody debris in red pine forests across the Great Lakes states, U.S.A. Can J For Res 29:1926-1934

EEA (2006) European forest types. EEA Technical Report 9, Luxembourg, $111 \mathrm{p}$

FAO (2004) Global Forest Resources Assessment Update 2005. Terms and definitions. FRA Programme Working Paper 83/E, Rome, $35 \mathrm{p}$

Fridman J, Walheim M (2000) Amount, structure, and dynamics of dead wood on managed forestland in Sweden. For Ecol Manag 131:2336

Führer E (2000) Forest functions, ecosystem stability and management. For Ecol Manag 132:29-38 
Green P, Peterken GF (1997) Variation in the amount of dead wood in the woodlands of the Lower Wye Valley, UK in relation to the intensity of management. For Ecol Manag 98:229-238

Hagemann U, Moroni MT, Makeschin F (2009) Deadwood abundance in Labrador high-boreal black spruce forests. Can J For Res 39:131-142

Harmon ME, Franklin JF, Swanson FJ, Sollins P, Gegory SW, Lattin JD, Anderson NH, Cline SP, Aumen NG, Sedell JR, Lienkaemper GW, Cromak K, Cummins KW (1986) Ecology of coarse woody debris in temperate ecosystems. Adv Ecol Res 15:133-302

Helms JA (1998) The dictionary of forestry. Society of American Foresters, Washington

Herrero C, Krankina O, Monleon VJ, Bravo F (2014) Amount and distribution of coarse woody debris in pine ecosystem of northwestern Spain, Russia and the United States. IForest 7:53-60

Holub SM, Spears JDH, Lajtha K (2001) A reanalysis of nutrient dynamics in coniferous coarse woody debris. Can J For Res 31:1894 1902

Hunter ML (1990) Wildlife, forests and forestry. Prentice Hall, Englewood Cliffs

INFC (2007) Le stime di superficie 2005. Autori: Tabacchi G, De Natale F, Di Cosmo L, Floris A, Gagliano C, Gasparini P, Genchi L, Scrinzi G, Tosi V, Inventario Nazionale delle Foreste e dei Serbatoi Forestali di Carbonio. MiPAF-Corpo Forestale dello Stato - Ispettorato Generale, CRA - ISAFA, Trento. Available at: http://www.infc.it

Jönsson MT, Jonsson BG (2007) Assessing coarse woody debris in Swedish woodland key habitats: implications for conservation and management. For Ecol Manag 242:363-373

Kirby KJ, Reid CM, Thomas RC, Goldsmith FB (1998) Preliminary estimates of fallen dead wood and standing dead trees in managed and unmanaged forests in Britain. J Appl Ecol 35:148-155

Krankina ON, Harmon ME (1994) The impact of intensive forest management on carbon stores in forest ecosystems. World Res Rev 6: $161-177$

Kruys N, Fries C, Jonsson BG, Lämås T, Ståhl G (1999) Wood-inhabiting cryptogams on dead Norway spruce (Picea abies) trees in managed Swedish boreal forests. Can J For Res 29:178-186

Kueppers LM, Southon J, Baer P, Harte J (2004) Dead wood biomass and turnover time, measured by radiocarbon, along a subalpine elevation gradient. Oecologia 141:641-651

La Fauci A, Mercurio R (2008) Caratterizzazione della necromassa in cedui di castagno (Castanea sativa Mill.) in Aspromonte. Forest 5: 92-99

Lombardi F, Lasserre B, Tognetti R, Marchetti M (2008) Deadwood in relation to stand management and forest type in Central Apennines (Molise, Italy). Ecosyst 11:882-894

Marage D, Lemperiere G (2005) The management of snags: a comparison in managed and unmanaged ancient forests of the Southern french Alps. Ann For Sci 62:135-142

Marchetti M, Lombardi F (2006) Analisi quali-quantitativa del legno morto in soprassuoli non gestiti: il caso di "Bosco Pennataro", Alto Molise. L'Italia Forestale e Montana 4:275-301

Mason F, Nardi G, Whitmore D (2005) Recherches sur la restauration des habitats du bois mort: l'exemple du LIFE "Bosco della Fontana" (Italie). In: Vallauri D, André J, Dodelin B, Eynard-Machet R, Rambaud D (eds) Bois mort et à cavités, une clé pour des forêts vivantes. Éditions Tec \& Doc, Paris, pp 285-291

Matthews G (1993) The carbon content of trees. Forestry Commission Technical Paper 4, Forestry Commission, Edinburgh, $21 \mathrm{p}$

Merganičová K, Merganič J, Svoboda M, Bače R, Šebeň V (2012) Deadwood in forest ecosystems. In: Blanco JA, Lo YH (eds) Forest Ecosystems - More than Just Trees, InTech Book: pp 81-108

Montes F, Cañellas I, Montero G (2004) Characterisation of coarse woody debris in two Scots pine forests in Spain. In: Marchetti M (ed) Monitoring and indicators of forest biodiversity in Europefrom ideas to operationality, vol 51, EFI Proceedings., pp 171180
Næsset E (1999) Relationship between relative wood density of Picea abies logs and simple classification systems of decayed coarse woody debris. Can J For Res 14:454-461

Nordén B, Ryberg M, Götmark F, Olausson B (2004) Relative importance of coarse and fine woody debris for the diversity of wood-inhabiting fungi in temperate broadleaf forests. Biol Conserv 117:1-10

Nunery JS, Keeton WS (2010) Forest carbon storage in the northeastern United States: net effects of harvesting frequency, post-harvesting retention, and wood products. For Ecol Manag 259:1363-1375

Paletto A, Tosi V (2010) Deadwood density variation with decay class in seven tree species of the Italian Alps. Scand J For Res 25:164-173

Paletto A, Ferretti F, Cantiani P, De Meo I (2012a) Multi-functional approach in forest landscape management planning: an application in Southern Italy. For Syst 21:68-80

Paletto A, Ferretti F, De Meo I, Cantiani P, Focacci M (2012b) Ecological and environmental role of deadwood in managed and unmanaged forests. In: Diez JJ (ed) Sustainable Forest Management, InTech book: pp 219-238

Pedlar JH, Pearce JL, Venier LA, McKenney DW (2002) Coarse woody debris in relation to disturbance and forest type in boreal Canada. For Ecol Manag 158:189-194

Pignatti G, De Natale F, Gasparini P, Paletto A (2009) Il legno morto nei boschi italiani secondo l'Inventario Forestale Nazionale. Forest 6: 365-375

Pregitzer KS, Euskirchen ES (2004) Carbon cycling and storage in world forests: biome patterns related to forest age. Glob Change Biol 10: 2052-2077

Radu S (2006) The ecological role of deadwood in natural forests. Environ Sci Eng 3:137-141

Ravindranath NH, Ostwald M (2008) Carbon inventory methods. Handbook for greenhouse gas inventory. Springer, Carbon Mitigation and Roundwood Production Projects

Rock J, Badeck FW, Harmon ME (2008) Estimating decomposition rate constants for European tree species from literature sources. Eur J For Res 127:301-313

Rondeux J, Sanchez C (2010) Review of indicators and field methods for monitoring biodiversity within national forest inventories. Core variable: Deadwood Environ Monit Assess 164:617-630

Rouvinen S, Rautiainen A, Kouki J (2005) A relation between historical forest use and current dead woody material in a boreal protected oldgrowth forest in Finland. Silva Fenn 39:21-36

Sandström F, Petersson H, Kruys N, Ståhl G (2007) Biomass conversion factors (density and carbon concentration) by decay classes for dead wood of Pinus sylvestris, Picea abies and Betula spp. in boreal forests of Sweden. For Ecol Manag 243:19-27

Shapiro S, Wilk M (1965) An analysis of variance test for normality (complete samples). Biometrika 52:591-611

Siitonen J (2001) Forest management, coarse woody debris and saproxylic organisms: Fennoscandian boreal forests as an example. Ecol Bull 49:11-41

Sollins P, Cline SP, Verhoven T, Sachs D, Spycher G (1987) Patterns of log decay in old-growth Douglas-fir forests. Can J For Res 17:1585-1595

Stokland JN, Tomter SM, Söderberg U (2004) Development of dead wood indicators for biodiversity monitoring: experiences from Scandinavia. In: Marchetti M (ed) Monitoring and indicators of forest biodiversity in Europe-from ideas to operationality, vol 51, EFI Proceedings., pp 207-226

Teissier du Cros R, Lopez S (2009) Preliminary study on the assessment of deadwood volume by French national forest inventory. Ann For Sci 66:302

Thomas JW (2002) Dead Wood: from Forester's Bane to Environmental Boon. In: Laudenslayer WF Jr, Shea PJ, Valentine BE, Weatherspoon CP, Lisle TE (eds), Proceedings of the symposium on ecology and management of deadwood in western forests, Reno, NV. USDA Forest Service General Technical Report PSW-GTR181, pp 3-9 
Tobin B, Black K, McGurdy L, Nieuwenhuis M (2007) Estimates of decay rates of components of coarse woody debris in thinned Sitka spruce forests. Forestry 80:455-469

Travaglini D, Barbati A, Chirici G, Lombardi F, Marchetti M, Corona P (2007) ForestBIOTA data on deadwood monitoring in Europe. Plant Biosyst 141:222-230

Vallauri D, André J, Blondel J (2003) Le bois mort, une lacune des forêt gérérs. Rev For Fr 2:99-112
Verkerk PJ, Lindner M, Zanchi G, Zudin S (2011) Assessing impacts of intensified biomass removal on deadwood in European forests. Ecol Indic 11:27-35

Waddell KL (2002) Sampling coarse woody debris for multiple attributes in extensive inventories. Ecol Indic 1:139-153

Zell J, Kändler G, Hanewinkel M (2009) Predicting constant decay rates of coarse woody debris - a meta-analysis approach with a mixed model. Ecol Model 220:904-912 